\title{
History and theory of Scripture
} translations

\author{
Jean-Claude Loba-Mkole (Hekima College/UBS, Nairobi). ${ }^{1}$ \\ Research Associate: Department of New Testament Studies \\ University of Pretoria
}

\begin{abstract}
This article argues for the importance of Bible translations through its historical achievements and theoretical frames of reference. The missionary expansion of Christianity owes its very being to translations. The early Christian communities knew the Bible through the LXX translations while churches today still continue to use various translations. Translations shape Scripture interpretations, especially when a given interpretation depends on a particular translation. A particular interpretation can also influence a given translation. The article shows how translation theories have been developed to clarify and how the transaction source-target is culturally handled. The articles discuss some of these "theoretical frames", namely the functional equivalence, relevance, literaryfunctional equivalence and intercultural mediation. By means of a historical overview and a reflection on Bible translation theories the article aims to focus on the role of Africa in translation history.
\end{abstract}

\section{INTRODUCTION}

The Christian faith as a whole "never exists except as translated into a culture" (Bosch 2002:447; Sanneh 2004:1). In the missionary expansion of Christianity, Scripture translations, often taken for granted, have served as the main catalyst, although it has not always received the necessary recognition. From a historical perspective, it rightly can be argued that Christianity owes its very being to translations. Translations unceasingly mediate the salvation of Christ Jesus from one culture to another, extending the open-ended meaning

\footnotetext{
${ }^{1}$ Jean-Claude Loba-Mkole, STD, PhD (Leuven), is lecturer at Hekima College and translation consultant with the United Bible Societies (Nairobi). Dr Loba-Mkole is a member of the International Advisory Board of HTS Theological Studies and a research associate of Prof Dr Jan G van der Watt, Department of New Testament at the Faculty of Theology, University of Pretoria.
} 
of incarnation and resurrection as much as possible. The time has come for Christians in Africa to take note of how much Christianity owes to translations. However, this can only happen when the translation communities come out and make their case out in appropriate forums (Church and public institutions).

It is interesting to note that Bible translation theories have emerged as the subject of research and training in Africa. Academic interests in translation theories are expressed in various publications and through the creation of different centers and departments of translation studies (cf University of South Africa, Nairobi Graduate School of Theology, University of Stellenbosch, Université Pédagogique Nationale in Kinshasa, Faculté de Théologie de l'Alliance Chrétienne in Abidjan, etc). In some cases, this interest manifests in very practical and specific questions such as those formulated by the Nairobi International School of Theology in 2006: What is going on in the field of translation theory and translation research? Are there any recent translation theories that are significantly different from those put forward by pioneers such as E Nida and others forty years or so ago? How can Bible translation in Africa contribute to translation theory/study? This article addresses these questions through a threefold working hypothesis: Is there anything going on in translation theory? Do recent translation theories significantly differ from those of $E$ Nida? Can Bible translation in Africa make a contribution to translation study? These issues will be tackled in the second part of this paper. However, the first part of this paper is devoted to the historical background of Bible translation practices. After presenting a working definition of Scripture Bible translation, this part will explore the origin, development and interpretative role of Scripture translations.

\section{ORIGINS OF SCRIPTURE TRANSLATIONS}

\subsection{Definition}

Translation is whatever a society recognizes as such, to the extent that everything can be called translation. It occurs almost everywhere, although it somehow remains "invisible". This applies, for example, to a brain that is translating thoughts into words, or an atomic fusion converting electric energy into light, or even a literary translation that has superseded its original. Generally speaking, Bible translation belongs to the category of literary and "artistic translation, which converts a source text into a target one. It also involves a process known as "trans-mediatization" or the transfer from one medium to another (e.g., from an oral text to a written one, from a written text to a painted one, from a printed text to an audio-visual one, from one script to 
another, i.e. transcription, transliteration and digitalization). Original languages for Biblical texts are Hebrew and Aramaic for the "First Testament", and Greek for the "Second Testament". John 19:20 mentions an amazing case where three source languages (Hebrew, Latin and Greek) were simultaneously used to deliver a message. Any translation process includes a lesser or greater degree of deletion, distortion, generalization, specification, or equivalence between the source text and the target text. The first four features of translation can be at work even when the same language is used for both source and target texts, like in the case of recension or revision.

Consequently, a translation is not a one-way process; rather, it is an intercultural phenomenon, which achieves its mediation through a strategy of give and take. Bible translation aims at sharing information and fostering the communion between the sender, the messenger and the receiver.

Furthermore, it might mean a prophetic act in terms of "trans-humanization" or communicating a "divine" message through a human and living exegesis or testimony (e.g., Is 7:14, 8:1-4; Hos 1:2-9; Jn 1:14, 18; Ac 15:12), as well as "trans-divinization" or transformation of human nature into a "divine" one (cf 2 Ki 2:11; Rm 6:5-11; 1 Cor 15:42-54). The sections that follow will focus especially on the history of Bible translations from a literary perspective.

\subsection{Origins of Scripture translations}

The history of Bible translations in Judeo-Christian traditions dates back to the fifth century BC when the Jewish elite, under the leadership of Ezra and later on Nehemiah, undertook to rebuild Jerusalem. Scribes "read from the scroll of the teaching of God, translating it and giving the sense; so they understood the reading" (Neh 8:8 Tanakh). During the fifth to fourth century BCE earliest or second century BCE, Samaritans produced a version of the Pentateuch and came up with what is called the "Samaritan Pentateuch". The latter consists of two layers, namely the "Palestinian text" (paleo-Hebrew script), which may date back to the fourth century BCE, and the actual "Samaritan revision", which originated from the second century BCE (Hasmonian period) and championed the central status of Shechem and Mount Gerizim. ${ }^{2}$

The situation depicted in Nehemiah 8:8 consists of an oral translation, most likely from Hebrew into Aramaic (the common language of the Jews at that time). The event of the Samaritan Pentateuch not only refers to a written translation, but also carries a considerable ideological input. However, despite the use of different languages or dialects (Hebrew, Aramaic or Samaritan) the

\footnotetext{
2 The "Massoretic text" $\left(9^{\text {th }}-10^{\text {th }}\right.$ century AD) adopted the later Assyrian "square" script or Tiberian System
} 
translation mentioned in Nehemiah 8:8 and the Samaritan Pentateuch both share a great deal of similarity as their source texts and target audiences belong to the same Semitic culture. Oral translations from Hebrew to Aramaic that were put into writings during the third and second centuries BCE are known as Targumim (paraphrases), the earliest on the Pentateuch being the Chaldaic Targum of Onkelos ( $3^{\text {rd }}$ century BCE).

From the third century BCE onwards, the endeavor to translate the Bible took an unprecedented step, as it moved from being a one-culture event to becoming an inter-cultural business. The Septuagint (LXX), which is the translation of the Hebrew Bible into Greek, constitutes the first historical and literary landmark bridging two different cultures, namely the Semitic culture and the Hellenistic one, although the Jews were still the main target. According to a legend found in the apocryphal Letter of Aristeas $(39,43,121)$ and which was repeated by Josephus (Ant 12.2.13), seventy-two elders (six representing each of the 12 Israelite tribes) carried out this translation at the request of Ptolemy II Philadelphus, king of Egypt (287-47 BCE) made on behalf of the Jewish Diaspora in Alexandria. In addition to the political dimension, the endeavor had a cultural and ethical dimension to it. The cultural dimension is represented by the fact that the letter indicates that LXX was to enrich the Alexandrian royal library with Jewish sacred writings. The ethical dimension is to be found in the words that the Letter of Aristeas attributes to the King Plolemy II Philadelphus and to the High Priest Eleazar. As reported by this letter, the King Ptolemy II Philadelphus ordered for the translators who were "men of noble life", "skilled in law" and "able to interpret it" (1:39). The High Priest Eleazar on his turn is reported to have qualified those translators as "good and true men, distinguished by their learning and worthy in every way" to represent "righteous purposes" (1:43). Aristeas himself calls them "men of finest character and highest culture" (3:121). The number of the translators of the LXX remains debatable: seventy-two (Aristeas), seventy (cf Ex 24:1, 9; Nm 11:25) or five. Each of these numbers is symbolical, representing either the tribes of Israel or the elders of Israel or the five books of Moses. Nevertheless, what is certain is that the LXX was the result of team work and was the most revolutionary undertaking that triggered the development of Bible translations in a very significant way. As Porter \& Hess (1999:14) put it: "The Septuagint is, of course, one of the most important translations ever made, and arguably the single most important from the ancient world."

\subsection{Development of Scripture translations}

Despite it being a translation done by non-Christian Jews, the Christians did not reject LXX. They only provided some revisions, such as those by Origen (+ 254), Hesychius (+311), and Lucian (+312), following the second century 
emendations done by Jewish proselytes Symmachus, Aquila and Theodotion. During the time of the early Church, the LXX served as the only sacred Scripture to which New Testament books were added to form a complete set of the Christian Bible. In Christian Antiquity, many versions of the First Testament were based on the LXX. These include Old Latin ( $2^{\text {nd }}$ century), the Egyptian or Coptic ( $2^{\text {nd }}$ century), the Ethiopic or Amharic ( $4^{\text {th }}$ century), the Gothic ( $5^{\text {th }}$ century), the Armenian ( $5^{\text {th }}$ century), the Georgian $\left(6^{\text {th }}\right.$ century), the Syriac $\left(7^{\text {th }}\right.$ century) and the Slavic (from $9^{\text {th }}$ century) translations.

Nevertheless, many early Church communities felt the need to have the Christian Scriptures translated from an original language. This accounts for the Syriac Peshitto version ( $2^{\text {nd }}$ century AD), the Latin "Vulgate" by Saint Jerome ( $5^{\text {th }}$ century), the Arabic version by Saadia ha-Gaon ( $10^{\text {th }}$ century) and the Persian version by Rabbi Jacob Tawus ( $16^{\text {th }}$ century).

The Vulgate gradually acquired the prestige previously reserved to the LXX and Peshitto among the majority of the Christians of antiquity. After being adopted by several writers in the fifth century, it became more widely used in the sixth century, and by the ninth century it spread in the entire Western Church. The Council of Trent (1546) recognized it as authoritative and it became the official Bible of the Roman Catholic Church.

The Roman Catholic Church had already adopted the Vulgate as her own Bible earlier on, while the Orthodox Church associated herself with the LXX, especially after the schism of 1054 . One can just imagine how the life of the Church in the East and West was influenced by the two direct translations from the originals until the advent of mixed translations. The first complete Bibles of mixed translations in European languages include those in English (Oxford 1380), German (Constance 1450), Italian (Venice 1471), Spanish (Valencia 1478), French (Antwerp 1530), Dutch (1526 Antwerp) and Portuguese (Lisbon 1784). Translations in other languages followed: Chinese (Serampur 1815-22), Malagasy (1835), Tswana (1857), Ga (Accra, 1866), Swahili (London 1895), Tamil (1796), Hindi (Serampur 1866-69) and Zulu (1883). These translations were based on eclectic source texts ranging from Hebrew manuscripts, the LXX, the Vulgate and other existing translations. For example, for the first edition of his Bible translation (1522-1545), Martin Luther made use of the Latin version of Lyra, the Hebrew-Latin Interlinear of Pagninus and an older German translation of the Vulgate (Knight 2003:13). This eclectic tendency can also be seen in Africa: "In the preparation of their work, many missionaries studied Hebrew, Greek and Latin" (Naude \& Van der Merwe 2002:7). Sometimes, many current translations are simply based on "other translations in the major languages of the colonial powers" (Naude \& Van der Merwe 2002:206). The issue of eclectic sources also affects translations based on original languages when a translator uses both MT and 
LXX readings in his/her work, or even when his/her critical edition of the "original text" betrays some degree of eclecticism (Porter \& Hess 1999:29).

In the Anglophone world, the first most authoritative Bible translation based on original languages is attributed to William Tindale (1526-34). It was superseded by the King James Version (1611), which became the Bible for English-speaking countries for about 250 years (Omanson 2001:449). Spanish speakers, on their turn, came up with the "Biblia del Oso", which was translated by Cassiodoro de Reina (1569) and revised by Cipriano Valera (1602). Since then, the two names were closely associated with the "Biblia del Oso" to the extent that even after many other revisions this version is called "Reina-Valera". This translation gradually became the Spanish counter-part of the English "King James Version". In the Francophone zone, "la Bible Louis Second" (1880) is widely used by the Protestants, while "la Bible de Jérusalem" (1955) is mainly favored by the Roman Catholics. "La Traduction Oecuménique de la Bible" (1988) is intended for all French-speaking Christian communities. Any translation carries the weight of the culture and language used as communication channels. This brings us to the problem of interpretation in the work of Scripture translations.

\subsection{Scripture translations and interpretations}

Bible translations and Bible interpretations are interwoven. Such is the extent of their interrelatedness that the practice of either one presupposes the other. Since the periods of the LXX and Targumim, Bible translation has always involved a great deal of hermeneutical competence, i.e. people who are skilled in the art and science of interpretation. In the process of translating, they interpret and make exegetical choices, as Barrera $(1998: 436,439)$ explains:

The simple translation of the terms tohu wabohu (Gn 1:2 "empty and void" or "formless chaos" by aoratos kai akataskeuastos, "invisible and disorganised" is a complete hellenisation ... Even more telling is the translation of the divine name ehyeh asher ehyeh (Ex 3:14) by ego eimi ho on, "I am the existing one". Likewise, Targum Neophiti inserts some words to Gn 2:15 to make Adam a wise student of the Torah " ... in order to work in the Torah and keep its commandments."

Even when St Jerome in his prologues to Old Testament books claims not to have changed the truth of the Hebrew texts, he nevertheless acknowledges that his renderings of the Fist Testament books tend to obey the authority of the Holy Spirit, the Gospels and the Apostles more. Furthermore, his translations betray a revision of Old Latin versions or a reinterpretation of the 
LXX. As a matter of fact, many translations from the ancient times until now use creative approaches that betray the interpretative choices of their authors and the needs of their audiences.

Gerald West (2005:3-29) finds that Bible translation is a dominant form of African biblical interpretations or hermeneutics. He argues that Bible translation consumes vast amounts of biblical interpretation and produces significant biblical scholarship. However, African biblical translation, according to West, often operates as if it were not part of African biblical hermeneutics. West (Loba-Mkole \& Wendland 2005:17) further explains:

First, African biblical translation is often not hermeneutical enough, by which I mean that it does not partake of and draw from the rich array of resources currently available to biblical hermeneutics generally. African biblical translation tends to be a hermeneutically unreflective practice. While technically competent in terms of biblical scholarship, African Bible translation seems reluctant to complete the hermeneutical circle by moving from what the text might have meant to what the text might mean in Africa ... Secondly, African biblical translation is often not African enough, by which I mean that it does not readily engage with African realities as the subject of its scholarship. African biblical translation tends to err on the side of missionary (in the broadest sense) meanings of the text and African context.

Any Bible translation is an interpretive exercise or a hermeneutical process. As much as a Scripture generally comes to the reader in a translated form, a translation is usually an interpreted text. However, the interrelatedness of translation and interpretation is often not clearly spelled out. On the contrary, much more attention is given to Bible translation theories.

\section{DEVELOPMENT OF BIBLE TRANSLATION THEORIES}

Among the many translation theories that have been documented and are being advocated count the literalist, functionalist, descriptive, text-linguistic, relevance, and interpretive, comparative, professional, literary-rhetorical or intercultural approaches. Four of these approaches will be discussed in this paper, namely functional equivalence, relevance, literary-functional equivalence and intercultural mediation approaches.

\subsection{Bible translation and functional equivalence}

In the history of Scripture translation, the name of E Nida is closely associated with the theory of functional equivalence. In this instance, translating consists of reproducing in the receptor language the closest natural equivalent both in 
meaning and in style of the source language message. It aims at communicating a message that is faithful to the original message, but clear and natural in the receptor's language. In order to achieve this, it proceeds by analysis, restructuring and transferring the source text to the target one. It is carried out in four stages. Ideally, one would understand that the first stage refers to the translation of a text translated by a single translator of a team of translators. The second stage represents the text being corrected by the team. The third stage consists of a text being reworked by the team (reviewer, stylist, manuscript examiner, translation consultant, translation committee, etc) in response to external remarks. The fourth and last stage is the result of a final re-reading of the translated text and approval by the team before proceeding to production. Nida has always recommended that Bible translations be done from original sources/cultures, but in such a way as to be meaningful for the target audience.

Although it had not been fully applied in many translations which claim to have performed the method of functional equivalence, it has nevertheless yielded some important results in terms of common language translations. In fact, since the last half of the $20^{\text {th }}$ century the majority of Bible readers use common language translations more increasingly (Arduini \& Hodgson 2004:310; Stine 2004:7). They include the Good News Bible, Français Courant, Français Fondamental, Die Gute Nachricht or the common language translations in Afrikaans, Akan, Swahili and Malagasy. It is an honor for Africa to also present some common language translations that have achieved a high standard of functional equivalence between the biblical original texts and the target languages.

Even if the functional equivalence had dominated the field of Bible translations for about half a century, this theory has been criticized in different ways. Some critics have pointed out that Nida's definition of translation is a declaration or manifesto which views communication in terms of the conduit metaphor (Wilt 2003:7). While Nida's definition assumes the message of a given text can be communicated, Wilt (2003:39) states that:

\footnotetext{
A person never sends a meaning, let alone the meaning, to another person; rather she sends an arrangement of signs that she intends to be understood in certain ways. Meaning depends on the hearer's interpretations as well as the speaker's intentions, and the hearer's interpretations are shaped by others' interpretations.
}

Even though it is accused of promoting the fallacy of conduit metaphor, Nida's functional equivalence has the merit of offering a clear definition that has proved to be more productive in the field of Bible translation. Furthermore, a 
communicator may not just intend to be understood in certain ways, but in some precise ways in which at least one can be central. Nida's insistence on getting the meaning or the message of a text can be understood as a way of identifying a central member or a salient feature of a cognitive category. Nida seems to have placed due emphasis on the cognitive aspects of communication.

\subsection{Bible translation and relevance}

In the light of new insights, translation is viewed as communication and goaldirected exchange involving mediators, texts and a medium. This exchange operates within a wider range of references, which includes cognitive, sociocultural, organizational and communication-situation frames. Consequently, translation goals are most likely to be shaped by these various frames. At least three different kinds of goals come into play: fundamental goals, which relate to socio-cultural, organizational, situational and cognitive models; conflicting goals, which might emerge from contradicting interests of different translation partners; and ritual communication goals pertaining to the models of communication needed (fellowship, participation, representation of shared beliefs, etc). Therefore, the translation process would request strategies for assessing the communication situation, facilitating cooperation, identifying goals and resources, providing academic and technical training; producing, evaluating and developing the translated texts. Communication itself is not always easy, but often complex as it entails negotiations between different frames of reference.

The model of relevance theory in translation is strongly influenced by communication theory. According to Gutt (2000:204; Naude \& Van der Merwe 2002:107-117), translation is an inter-lingual interpretive usage (translation as secondary communication vs direct communication), which proceeds by comparisons of the observable input (original text) and output (translated text). This process aims at an optimal relevance, which refers to the attitude of the hearer who expects his/her interpretation to yield adequate contextual effects at minimal processing cost (Gutt 1991:20). In other words, translation deals with explicatures (information linguistically encoded in the text) and implicatures (assumptions expected to be decoded from the context) (Snuth 2000:77). In this transaction, the context of communication plays a major role in helping the audience to establish a mutual cognitive environment with the author, namely situational, inter-textual, co-textual elements (Pattemore 2003:190). 
Owing to the relevance theory, translation theory could benefit from new insights developed in communication theory and cognitive linguistics. It has been used to interpret some Scripture passages such as the quotationformula in Matthew 2 (France 1981:233-251) or the quotations and repetitions in Revelations (establishing a mutual cognitive environment in terms of numbered septets of seals, trumpets and bowls) (Pattemore 2003:191). A major critical challenge to the relevance theory lies in its reductionism (i.e. relevance becomes the criterion for every communication process). It also remains highly theoretical and less practical for a translator (Gutt 2000:306).

\subsection{Bible translation and literary-functional equivalence}

Literary-functional equivalence constitutes a new development of functional equivalence, with specific emphasis on literary features, which many common language translations have often neglected (Wendland 2004:32, 45). It depicts translation as a mediated act of communication (genre, context, settings, cognitive and skopos frames) that represents in a given language the variety of expressive dynamics (great impact, appeal and beauty) of diverse texts of Scripture. Special attention is paid to the target language through a literaryrhetorical analysis and application of the target language's verbal forms (constitution - collection - classification - comparison - compensation creation - examination - and - criticism) (Wendland 2004:266-272).

Viewing the Bible as literature, literary-functional equivalence underscores that a Bible translation needs to reflect literary features of the source texts and those of the target audience as well. Awareness of literary features implies among other things the effort to identify the unity and the diversity of a biblical text: the unity is revealed through literary devises of connectivity, intertextuality and archetypes, while some significant difference in literary composition might serve to indicate a distinctive section. Furthermore, the structure of a text, and hence its understanding, depends on other literary devices such as genre and patterning (parallelism, chiasmus, intercalation, inclusio, contrast, comparison, causation-substantiation, climax, pivot, particularization-generalization, purpose, anticipation, retrospection, summarization, interrogation, etc) (Wilt 2003:208-211). In addition, literary elements such as foregrounding (prominence and progression), imagery (metaphor, metonymy, and euphemism), phonicity (rhythm, alliteration, onomatopoeia) and dramatics (direct speeches, dialogues) all serve a communicative function which needs to be integrally conveyed. Wendland has carried out many case studies, demonstrating how this translation model can 
be relevant and effective in Chichewa language (a major African language spoken in Zambia and Malawi).

Literary-functional equivalence appears to be an ideal model, as it enhances both form and meaning based translations. It strives to foster a discourse-centered model that integrates genre-based perspectives, prominent pragmatic-functional components, situational frames of reference, artistic and rhetorical features as well as oral-aural dimensions. It may, however, call for a more balanced perspective between literary and historical approaches.

\subsection{Intercultural mediation}

"Equivalence" has become a key concept in Bible translation. It offers a cognitive frame to accommodate and articulate a good number of translation models (literary equivalence, functional equivalence, relevant equivalence or literary-functional equivalence). This concept seems to be perhaps wrongly so, associated with a two dimensional process, namely the source language/culture and target language/culture. A third dimension, which can be called tradition, is often overlooked, although it might strongly influence the understanding of the source culture and that of the target one too.

Approaching translation as an intercultural mediation is an attempt to restate translation as a triple-dimension process that includes some representations of the original culture, those of the tradition and those of the current target culture. Furthermore, an equivalence model does not pay adequate attention to non-literary forms, which a model of intercultural mediation would include.

Intercultural mediation is a dialogical process that involves not only literary works, but also artistic symbols and the work of human heroes that ensure the transmission of the biblical text from an original culture to a contemporary one, including the heritage from a traditional culture (LobaMkole 2005:1-2; 2006a:19; 2006b:51-70). In this approach, the epistemological privilege is equally granted to all three sets of culture, namely to the original culture (out of respect for its canonicity), to the traditional culture (out of respect for its elderliness) and to the contemporary culture (out of respect for its people who are the only ones living in flesh and blood in the here and the now). When operating in an African society, intercultural mediation embraces three main epistemological values: African worldview (that which promotes life is what is valuable), Jesus (that which concurs with Jesus' message is valuable) and a Christian traditional value (that which a Christian tradition values is to be respected, but constantly assessed). In terms of ethical values, intercultural mediation includes faithfulness to the original culture (ethics of faithful representation), loyalty to the current culture 
(ethics of service) and a critical honesty toward the tradition (ethics of active solidarity). Translating the identity of the Holy Spirit in the Democratic Republic of Congo would imply a dialogical process between the meanings shared by the present Congolese Christianity and the meanings inherited from the New Testament original cultures, as well as those from Church traditions.

\section{CONCLUSION}

Historical and theoretical perspectives show that Scripture translations constitute a catalyst factor in the development of humanity in general and that of Christians in particular. The translation process fosters not only literary forms, but also other entities of a given culture. The role Africa has played in the history of Scripture translation since the event of the LXX is impressive. Nevertheless, Africa still needs to invest and make a bigger contribution towards the development of appropriate translation theories that can be used by Bible translation teams and that can also be discussed in different theological institutions. In summarizing, I would like to briefly answer the questions which have prompted the writing of this article and which have become its writing hypothesis.

- Is anything happening with regard to translation theory? Given the translation theories and models discussed in this article (cf relevance theory, literary-functional equivalence, or intercultural mediation), the answer is "yes".

- Are recent translation theories significantly different from those of Nida? This question cannot be answered by a definite "yes" or a "no". If we take into account the emphasis (specific contribution) of each theoretical frame, then there is some difference. However, in practice the difference between translations rigorously achieved from these otherwise overlapping approaches (functional equivalence, relevance, literary-functional equivalence, intercultural mediation) might not be that significant.

- Can Bible translation in Africa make a contribution towards translation study? Some Bible translations in Africa (Akan, Afrikaans, Malagasy, Swahili, etc) have already contributed or are striving to set a high standard of functional equivalence between original biblical texts and African languages. Moreover, translation centers (Abidjan, Kinshasa, Pretoria, Stellenbosch, etc) are emerging in Africa, as well as interest in publishing translation related studies. However, much still needs to be 
done to integrate African biblical scholarship and African Bible translation practices.

\section{Works consulted}

Arduini, S \& Hodgson, R (eds) 2004 Similarity and difference in translation. Rimini: Guaraldi. (Nida Institute for Biblical Scholarship.)

Barrera, J T 1998 The Jewish Bible and the Christian Bible: An introduction to the history of the Bible. Grand Rapids, Ml: Eerdmans.

Bosch, J D 2002. Transforming mission: Paradigm shifts in theology of mission. New York: Orbis Books.

De Waard, J \& Nida, A E 1986. From one language to another: Functional equivalence in Bible translating, Nashville, TN: Thomas Nelson.

France, R T 1981. The formula-quotations of Matthew 2 and the problem of communication. New Testament Studies 27: 233-51.

Greenslade, S L 1963. The Cambridge history of the Bible, Vol 3: The West from the Reformation to the Present Day. Cambridge: Cambridge University Press.

Gutt, E A 1991. Relevance theory: A guide to successful communication in translation. Dallas, TX: UBS.

Gutt, E A 2000. Translation and relevance: Cognition and context. Manchester: St Jerome.

Hallo, W W (ed) 1997. The context of Scripture, Vol. 1: Canonical compositions from the Biblical world. Cleveland, $\mathrm{OH}$ : Pilgrim.

Hodgson, R \& Soukoup, A P (eds) 1997. From one medium to another: Basic issues for communicating the Scriptures in New Media. Lanham, MD: Sheed \& Ward.

Knight, K (ed) 2003. Catholic Encyclopedia. Online Edition.

Lembaga Alkitab Indonesia 2005. One Bible many versions: Proceedings of the Indonesian Bible Society's Golden Jubilee Seminar. Jakarta: Lembaga Alkitab Indonesia.

Loba-Mkole, J-C 2005. Triple heritage: Gospels in intercultural mediations. Kinshasa: CERIL.

Loba-Mkole, J-C 2006a. Rise of intercultural exegesis in Africa. Hekima Review 35, 9-22.

Loba-Mkole, J-C 2006b. Ethics of a business manager: Intercultural exegesis of Luke 16:1-18. Hekima Review 36, 51-70.

Loba-Mkole, J-C \& Wendland, R E (eds) 2005. Interacting with Scriptures. Nairobi: Acton.

Mojola, O A \& Wendland, R E 2003. Scripture translation in the era of translation studies, in Wilt 2003:1-25.

Mojola, O A 1999. God speaks in our languages: Over 150 years of Bible translation in Kenya, Tanzania and Uganda. Nairobi-Dodoma-Kampala: Bible Societies of Kenya, Tanzania and Uganda.

Mojola, O Aloo 2004. Similarity, identity, and reference across possible worlds: The translation of proper names across languages and cultures, in Arduini \& Hodgson 2004:259-272. 
Naude, J A \& Van der Merwe, C H J (eds) 2002. Contemporary translation studies and Bible translation: A South African perspective. (Acta Theologica Suppl 2). Bloemfontein: University of the Free State.

Nida, A E 1964. Toward a science of translating. Leiden: Brill.

Nida, A E \& Taber, C 1969. The theory and practice of translation. Leiden: Brill. Omanson, R (ed) 2001. Discover the Bible. New York: United Bible Societies.

Pattemore, S 2003. Souls under the Altar: Relevance theory and the discourse structure of revelation. New York: United Bible Societies. (UBS Monograph Series 9.)

Porter, E S \& Hess, S R (eds) 1999. Translating the Bible: Problems and prospects. Sheffield: Sheffield Academic Press. (JSNT Suppl Series 173.)

Sanneh, L 2004. Translating the message: The missionary impact on culture. New York: Orbis Books.

Snuth, K G 2000. Bible translation and relevance theory: The translation of Titus. Unpublished doctoral dissertation. University of Stellenbosch.

Stine, P C 2004. Let the words be written. The lasting influence of Eugene A Nida. Atlanta: Society of Biblical Scholarship.

The Cambridge History of the Bible 1963-1975. Cambridge: Cambridge University Press.

Tov, E 1992. Textual criticism of the Hebrew Bible. Minneapolis, MN: Fortress.

Wendland, R E 2000. A form-functional, text-comparative method of translation, teaching, and checking. Notes on Translation 14(1), 7-27.

Wendland, R E 2002a. Analysing the Psalms: With exercises for Bible students and translators, rev ed. Dallas, TX: SIL International.

Wendland, R E 2002b. Towards a "literary translation of the Scriptures" with special reference to a "poetic" rendition, in Naude \& Van der Merwe 2002:64-201.

Wendland, R E 2002c. A literary-rhetorical approach to biblical text analysis and translation, in Wilt 2003:179-230.

Wendland, R E 2004. Translating the literature of Scripture: A literary-rhetorical approach to Bible translation, Dallas, TX: SIL International.

Wendland, R E \& Loba-Mkole, J-C (eds) 2004. Biblical texts and African audiences. Nairobi: Acton.

West, O G 2005. African biblical hermeneutics and its relevance for Bible translation in Africa, in Loba-Mkole \& Wendland, 2005:3-29.

West, O G \& Dube, W M (eds) 2000. The Bible translation in Africa: Transactions, trajectories and trends. Leiden: Brill.

Wilt, T (ed) 2003. Bible translation: Frames of reference. Manchester: Saint Jerome.

Yorke, G \& Renju, P (eds) 2004. Bible translation and African languages. Nairobi: Acton.

Zogbo, L \& Wendland, R E 2000. Hebrew poetry in the Bible: A guide for understanding and for translating. New York: United Bible Societies. 